Öztürk, Ahmet Erdi, and İştar Gözaydın. "A Frame for Turkey’s Foreign Policy via the Diyanet in the Balkans." Journal of Muslims in Europe 7, no. 3 (2018): 331-350.

Submitted: 26 November 2016

Accepted: 7 April 2017

Published online: 11 October 2017

\title{
A Frame for Turkey's Foreign Policy via the Diyanet in the Balkans
}

\begin{abstract}
Ahmet Erdi Öztürk: University of Strasbourg/Linköping University (correspondent author), aerdiozturk@gmail.com, University of Strasbourg, 4 Rue Blaise Pascal, 67081 Strasbourg, Fransa
\end{abstract}

İştar Gözaydın: Helsinki Citizens’’ Assembly, Istanbul

\begin{abstract}
This article deals with Turkey's increasing involvement and activism in the Balkans between 2002 and 2016, under the government of the Justice and Development Party. The central focus is Turkey's pliable state apparatus; the Presidency of Religious Affairs and its activities in the region. The article therefore aims to answer the following questions: Why does Turkey use these various state apparatuses specifically as a foreign policy tool and how does their influence differ from country to country? What factors determine the scope of activity of Turkish transnational state apparatuses in the case of each country? And, how do local actors and public opinion respond to Turkey's newly-emerging activities in the region?
\end{abstract}

Keywords: Diyanet; Islam; strategic depth; constructivism; the Balkans; Turkey

\section{Introduction}

The last two decades of the twentieth century have witnessed the return of religion to the mainstream of political life in an array of settings around the world. This has been a period in which religion has been a major factor in international relations ${ }^{1}$ and the world's political agenda has been face to face with religiously based tensions in many places, including the

\footnotetext{
${ }^{1}$ See, for example, Falk, Richard, Religion and Humane Global Governance (New York: Palgrave, 2001); Johnston, Douglas (ed.), Faith-Based Diplomacy: Trumping Realpolitik (Oxford: Oxford University Press, 2003); Petito, Fabio, and Pavlos Hatzopoulos (eds), Religion in International Relations: The Return from Exile (New York: Palgrave, 2003); Jonathan Fox and Shmuel Sandler, Bringing Religion into International Affairs (New York: Palgrave Macmillan, 2004); Thomas, Scott M., The Global Resurgence of Religion and the Transformation of International Relations: The Struggle for the Soul of the Twenty-first Century (New York: Palgrave Macmillan, 2005); Hanson, Eric O., Religion and Politics in the International System Today (New York: Cambridge University Press, 2006); Haynes, Jeffrey, An Introduction to International Relations and Religion (Essex: Pearson Longman, 2007); Banchoff, Thomas (ed.), Religious Pluralism, Globalization, and World Politics (Oxford: Oxford University Press, 2008); Haynes, Jeffrey (ed.), Routledge Handbook of Religion and Politics (London: Routledge, 2009).
} 
Middle East, the Caucasus and the Balkan Peninsula. During the Cold War, religion was a tool of foreign policy, as, for example, in Stalin's instrumentalisation of the Russian Orthodox Church but, since the 1990s, the international role of religion has become more visible and almost all the related publications refer to the fact that there is a global resurgence of religion in international relations. ${ }^{2}$ In discussions of the Westphalian legacy, ${ }^{3}$ changing paradigms of international relations and the rise of belief-based diplomacy have to a large extent become the common denominator in all relevant studies. In the meantime, the contemporary world and humanity have been suffering from the emergence of fundamentalist and radical religious movements, which have been carrying out violence worldwide in disputes and terrorist activities. Currently, Al-Qaeda, Aqmi, Hezbollah, Boko-Haram and Islamic State are seemingly highly active and so it appears that religion is going to retain its importance in world politics.

In these circumstances, Turkey's November 2002 elections were a watershed moment that elicited intense reaction across the political divide. The Justice and Development Party (Adalet ve Kalkınma Partisi - AKP) captured close to half of the popular vote and secured a majority of seats in the Turkish Grand National Assembly (Türkiye Büyük Millet Meclisi TBMM). Having endured chronically weak and unstable coalition governments for over a decade, the prospect of single-party government and a unified direction for the country under the charismatic and intense leadership of Recep Tayyip Erdoğan (who became prime minister in 2003 and president in 2014) proved a welcome development for many. ${ }^{4}$ Nevertheless, responses to the AKP's landslide election victory were mixed. On the one hand, many observers expressed scepticism (and even outright alarm) at the prospects for Turkey's secularist regime, given the AKP's Islamist roots. ${ }^{5}$ Indeed, the AKP originated in the National Outlook Movement (Milli Görüş Hareketi), which was established in 1970s with an Islamist and statist agenda and promoted the use of Sunni Islam in foreign policy.

\footnotetext{
${ }^{2}$ Banchoff, Religious Pluralism; Falk, Religion and Humane Global Governance; Fox and Sandler, Bringing Religion into International Relations; Haynes, Jeffrey, Religion and Development: Conflict or Cooperation? (New York: Palgrave Macmillan, 2007).

${ }^{3}$ Thomas, Global Resurgence; Carlson, John D., and Erik C. Owens, The Sacred and the Sovereign: Religion and International Politics (Washington, DC: Georgetown University Press, 2003).

${ }^{4}$ Insel, Ahmet, "The AKP and normalizing democracy in Turkey", South Atlantic Quarterly, 102.2 (2003), 293308; Yavuz, M. Hakan (ed.), The Emergence of a New Turkey: Democracy and the AK Parti (Salt Lake City: University of Utah Press, 2006).

${ }^{5}$ Coskun, Bezen, "The Triumph of an Islamic Party in Turkey: Effects of the Democratisation Process on the Rise of the Justice and Development Party (AKP)", Interdisciplinary Journal of International Studies, 1 (2003), 59-72; Haynes, Jeffrey, "Politics, identity and religious nationalism in Turkey: From Atatürk to the AKP", Australian Journal of International Affairs, 64.3 (2010), 312-27.
} 
On the other hand, the AKP'S victory was greeted both at home and abroad with a high degree of cautious optimism, not only because of the prospect of stable one-party government, but also because of the AKP's credible commitments to European Union (EU) reform, economic stability and development, and its well-articulated and mainstream agenda of political liberalisation and democratic reform. ${ }^{6}$

Through the first decade of the 2000s, the AKP established itself as the dominant elected power in Turkey, becoming the first party in Turkey since 1957 to win more than three successive general elections. Early on, the party won kudos for its explicit public commitment to the Turkish understanding of secularism ${ }^{7}$ and its cautious approach in confronting the Kemalist establishment, ${ }^{8}$ particularly the military and the bureaucracy. Perhaps more significantly, the party's steadfast implementation of a wide range of political and economic reforms and its championing of the EU-accession process garnered praise both at home and abroad. ${ }^{9}$ From 2010, however, the party took what many scholars have called an authoritarian turn and a number have argued that the result is that Turkey has essentially become an authoritarian system ${ }^{10}$ and religion in Turkey and abroad has become the main topic of public debate.

Turkey's rapid political transformation has thus been formative and its multiple dimensions are legion. Nowhere is this truer than in the domain of Turkish foreign policy. From the 1950s, Turkey's foreign policy had adopted a generally realist orientation centred on three enduring principles - Westernization, a commitment to a stable international order, and strict adherence to international law. ${ }^{11}$ Since 2002, however, scholars have noted Turkey's more active and culturally and ideologically driven foreign policy, primarily in the former Ottoman territories, but also globally. The instrumentalisation of a Turkified Ottoman history, the

\footnotetext{
${ }^{6}$ Dagi, Ihsan, "Turkey's AKP in Power", Journal of Democracy, 19.3 (2008), 25-30; Fuller, Graham E., "Turkey's strategic model: Myths and realities", Washington Quarterly 27.3 (2004), 51-64;

${ }^{7}$ Laiklik, in the Turkish political system is far from being a separation between the religion and state on the French model. On the contrary, in the Turkish approach since 1924, secularism means the control and regulation of religious bodies in order to impose the secularisation of Turkish society. Thus, the Diyanet was for decades a nationalist secularisation apparatus. For further details, see Akgönül, Samim, Laïcité en débat: Principes et représentations en France et en Turquie (Strasbourg:Presses Universitaires de Strasbourg, 2009).

${ }^{8}$ Kemalism consists of the political, economic and social principles advocated by Kemal Atatürk and designed to create a modern secular Turkish state out of a portion of the Ottoman Empire.

${ }^{9}$ Saatcioglu, Beken, "Unpacking the compliance puzzle: The case of Turkey's AKP under EU conditionality", KFG Working Paper, 14 (Berlin: Freie Universität Berlin, 2010).

${ }^{10}$ Esen, Berk, and Sebnem Gumuscu, "Rising competitive authoritarianism in Turkey", Third World Quarterly, 37.9 (2016), 1-26; Akkoyunlu, Karabekir, and Kerem Öktem, "Existential insecurity and the making of a weak authoritarian regime in Turkey", Southeast European and Black Sea Studies, 16.4 (2016), 505-27. Baser, Bahar, and Ahmet Erdi Öztürk (eds), Authoritarian Politics in Turkey: Elections, Resistance and the AKP (London: I.B. Tauris, 2017).

${ }^{11}$ Oran, Baskın, “Türk Dış Politikası: Temel İkeleri ve Soğuk Savaş Ertesindeki Durumu Üzerine Notlar”, Ankara Üniversitesi Siyasal Bilgiler Fakültesi Dergisi, 51.1 (1996), 353-70.
} 
idealisation of Ottoman culture and the normalisation of Sunni Islam, under the influence of Ahmet Davutoğlu ${ }^{12}$ and his foreign policy doctrine of "strategic depth", ${ }^{13}$ have been the motivating force behind this shift. The novelty of Davutoğlu's perspective is its definition of Turkey as a state neither at the periphery of Europe nor at the periphery of the Middle East. Rather, according to Davutoğlu, Turkey sits (as it did in Ottoman times) prominently at the crossroads of the two continents, and is thus a pivotal centre, mainly due to its unique geographical, historical and cultural links with both regions. In other words, during the AKP period, Turkey has shifted its foreign policy identity by describing itself as the inheritor of a long-standing Ottoman cultural tradition, and attempting more actively to influence former Ottoman territories. ${ }^{14}$ Moreover, many have observed a distinct "soft power" emphasis in this approach as Turkey has reached out culturally and economically in its relations with nonWestern states from Africa to the Caucasus. ${ }^{15}$ In the constructivist perspective in international relations (IR) theory, these changes in Turkish policy can be attributed to a reformulation and a transformation of how the Turkish state defines its own identity internally and externally.

With this background in mind, this article mainly focuses on the Diyanet (Diyanet $\dot{I}_{s} l e r i$ Başkanlığ - Presidency of Religious Affairs), one of the key ideological apparatuses of the Turkish state, which has been utilised during the AKP period to increase Turkey's sphere of influence in the Balkans. Previous studies have noted Turkey's new Balkan activism, but have adopted a rather broad-brush approach by focusing on Turkish diplomacy in the region without a deep analysis of the underlying factors such as culture, kin, language and, especially, religion. This study argues that the component of "religious diplomacy" deserves extra attention not only because it is a central factor that has been under researched, but because utilising religion while getting involved in other countries' public spheres gives rise to a variety of reactions there. The

\footnotetext{
${ }^{12}$ Ahmet Davutoğlu is a Turkish academic, politician and former diplomat who served as prime minister of Turkey and leader of the AKP from August 2014 to May 2016. He previously served as the Minister of Foreign Affairs from 2009 to 2014 and from 2003 to 2009 was chief advisor to Recep Tayyip Erdoğan during his term as prime minister. He was elected as an AKP Member of Parliament for Konya in the 2011 general election and was reelected as an MP in both the June and November 2015 general elections. He resigned as prime minister on 22 May 2016. Davutoğlu made Time magazine's list of the 100 most influential people in the world for 2012. Time commented: "The country's external outlook has been the design of scholar turned Foreign Minister Ahmet Davutoğlu. Turkey has been unequivocal in siding with the Arab and Balkan peoples in their revolts against autocratic regimes" (Mohyeldin, Ayman, "Ali Babacan and Ahmet Davutoglu", Time, 18 April 2012)

${ }^{13}$ Strategic Depth is a book published by Davutoğlu in 2001. It outlines the central elements of the foreign policy doctrine of the same name, arguing that a nation's value in world politics is predicated on its geostrategic location and historical depth. Following the logic of Davutoğlu's theory, Turkey is uniquely endowed both because of its location in geopolitical areas of influence, particularly its control of the Bosphorus, and its historical legacy as heir to the Ottomans. It is generally accepted that strategic depth has been the main doctrine informing Turkish foreign policy during the AKP period.

${ }^{14}$ Danforth, Nicholas, "Ideology and pragmatism in Turkish foreign policy: from Atatürk to the AKP", Turkish Policy Quarterly, 7.3 (2008), 83-95.

15 Aras, Bülent, "The Davutoglu era in Turkish foreign policy", Insight Turkey, 11.3 (2009), 127-42.
} 
study also notes that Turkish foreign policy has been trying to establish both a Turkish type of Sunni Islamic exceptionalism and hegemony by instrumentalising the Diyanet. The Diyanet's activities take place at the intersection of Turkey's neo-Ottoman ${ }^{16}$ ambitions, its newlyemerged kin and diaspora policy, and its commitment to belief-based transnational solidarity. By adopting a critical approach, the article will challenge the existing literature, which tends to celebrate Turkey as a rising power and treat its activism unproblematically. Rather than taking things for granted, it will question the scope, impact and contention of these activities.

\section{Conceptualisation and theoretical discussions}

At the risk of oversimplifying a complex and diverse theoretical tradition, it is true to say that realism generally perceives the world as a harsh and a dangerous place. Realist theory asserts that the condition of anarchy among states conditions them to pursue their individual interests competitively. Although realism has traditionally been the dominant paradigm in IR, since the end of the Cold War it has been the subject of intensifying critique from scholars working within the emerging constructivist paradigm. The structural theory outlined in Kenneth Waltz's famous study, Theory of International Politics, has been a particular target of constructivist arrows. Waltz argues that every political and social system is composed of its own structure and interacting units. His theory is understood as "structural" in the sense that it centres on the effects of the structure of the international system when it seeks to explain outcomes in international politics. ${ }^{17}$

Constructivist scholars challenge the capacity of realist precepts to explain the state of the changing international system, especially after the Cold War. According to them, structural realism misses the point that intersubjectively-shared ideas shape behaviour by constituting the identities and interests of international actors. Among various criticisms, Alexander Wendt has provided one of the most important. In his study, Social Theory of International Relations, he clarifies the central claims of the constructivist approach, presenting both a structural and an idealist framework that contrasts with the individualism and materialism that underpin much mainstream international relations theory. He builds a cultural theory of international politics that holds that the tendency of states to take on the social role of "enemy", "rival" or "friend" under differing conditions of anarchy is central. Wendt emphasises that the varying cultures of

\footnotetext{
${ }^{16}$ Uzgel, İlhan, and Volkan Yaramış, “Özal'dan Davutoğlu'na Türkiye'de Yeni Osmanlıcı arayışlar”, Doğudan, 16 (2010), 36-49.

${ }^{17}$ Waltz, Kenneth N, Theory of International Politics (Long Grove: Waveland Press, 2010).
} 
anarchy - Hobbesian, Lockean and Kantian -shape social role adoption in important ways. For Wendt, a Hobbesian culture of anarchy is the "law of the jungle" and conditions states to adopt the social role of enemy in a war of all against all. Lockean anarchic culture, in contrast, promotes the adoption of social roles of competitive rivalry. Finally, Wendt's conception of a Kantian culture of anarchy draws on Immanuel Kant's thesis of perpetual peace. Here, states are conditioned to see one another in a context of non-violent cooperation and mutual aid. ${ }^{18}$ In sum, these cultures of anarchy constitute intersubjective ideational structures for states, which condition their interests and capabilities and generate tendencies in the international system.

Constructivism's challenge to realist dominance in international relations theory since the 1990s has spawned a rash of new research into the foreign policy behaviour of states, and in particular that of key emerging states in world politics, such as Turkey. Indeed, there has been a renaissance in the study of Turkish foreign policy in the wake of the AKP's 2002 victory, much of it informed by the new constructivist paradigm. Kemal Kirişçi’s study of Turkish foreign policy, for instance, has pointed to shifts in Turkish foreign policy orientation since the early 2000s that have reshaped Turkish relations with, and approaches to, the EU, Armenia, Greece and many others. In addition, while scholars rightly acknowledge that much of the groundwork for Turkey's recent foreign policy transformation was laid during Turgut Özal's period as prime minister and president (1983-1993), it is undoubtedly the case that an unprecedented paradigm shift in foreign policy orientation and behaviour has occurred under the AKP. ${ }^{19}$ It is true that before 1980s there were also some shifts in Turkish foreign policy in 1950s, for example, with the radical decision to join Western institutions, or in 1960s, with some attempts to create the links with Soviet world - but one must acknowledge that the structure of foreign policy has never been challenged as deeply as during the AKP period. Some experts contend that the foreign policy shift is a direct reflection of the AKP's transformative domestic liberalisation agenda, which, as mentioned above, has also been unprecedented. In any case, scholars agree that it is the dynamic leadership of Erdoğan himself, under the guidance of Davutoğlu and his strategic depth doctrine, that has been the driving motor of Turkey's foreign policy transformation.

\section{Turkey's outreach to the Balkans}

\footnotetext{
${ }^{18}$ Wendt, Alexander, Social Theory of International Politics (Cambridge: Cambridge University Press, 1999).

${ }^{19}$ Kirişçi, Kemal, "The transformation of Turkish foreign policy: The rise of the trading state", New Perspectives on Turkey, 40.1 (2009), 29-57.
} 
The end of the Cold War and the resulting superpower competition has had major repercussions on global and regional politics. In the 1990s, almost all states sought to adjust their positions to conditions in the new international environment, and Turkey was certainly one of the prominent countries to transform its political and strategic visions in accordance with the new climate. ${ }^{20}$ Although major changes actually started after the end of the Cold War, Turkey's new foreign policies, globally speaking, emerged earlier with Turgut Özal. In other words, one can argue that Özal created a new foreign policy, which in journalist Cengiz Çandar's words, “constituted the funeral of Kemalism". ${ }^{21}$ Özal defined himself as coming from a relatively reformist Turkish centre right. However, although liberal-conservative politics had been in the Turkish political arena since the 1950s, Özal's foreign policy approach was quite different. ${ }^{22}$

Although Turkey maintained both political and economic relations with the Balkan countries during the Cold War period, they did not fulfil their real potential. One may easily argue that one of the main reasons for these limited relations was the domination of the former Soviet Union over most parts of the region. ${ }^{23}$ In the aftermath of the Cold War, there was a discernible increase in Turkey's interest and involvement in the Balkan Peninsula (and also through the instrumentalisation of assumed shared ethnic roots with Central Asia). There were many reasons for this new infatuation with the Balkans. First, the new Turkish foreign policy approach implemented by Özal aimed to establish warm relationships with parties that had historical ties. At this point, it should be noted that, even after Özal's death, Turkey's new Balkan policy continued to take almost the same line. In this respect, Turkey initially tried to establish some common projects with countries where there were minorities that shared a religious and/or ethnic heritage with Turkey. Second, the fragmentation of Yugoslavia, which was accompanied by violent ethno-nationalist conflicts in Bosnia and Kosovo, seriously undermined regional stability and increased the possibility of a major conflict that could spill over into Turkey. ${ }^{24}$ Furthermore, ethnic and religious conflicts in the region aroused interest and concern in Turkey because of the existence of both historical ties and a large number of

\footnotetext{
${ }^{20}$ Sayari, Sabri, "Turkish foreign policy in the post-Cold War era: The challenges of multi-regionalism", Journal of International Affairs, 54.1 (2000), 169-82.

${ }^{21}$ Interview with Cengiz Çandar, in Sezer, Metin, and Cem Dizdar, 2. Cumhuriyet Tartışmaları (Second Republic Debates) (Ankara: Başak 1993), p. 91.

${ }^{22}$ Gözen, Ramazan, Turkey's Delicate Position between NATO and the ESDP (Ankara: Center for Strategic Research, 2003).

${ }^{23}$ Uzgel, İlhan, "Doksanlarda Türkiye için bir işbirliği ve rekabet alanı olarak Balkanlar", in En uzun on yzl, G. Özcan and Ş. Kut (eds) (Istanbul: Büke Yayınları, 1998), pp. 403-44.

${ }^{24}$ Sayari, "Turkish foreign policy".
} 
Turks and Muslims who had migrated to Turkey from the Balkan Peninsula over the previous century or more. ${ }^{25}$

The AKP opted for a relatively new model of engagement in the Balkan Peninsula, entailing active cooperation with religious networks, cultural platforms and state apparatuses. One of the main reasons for this shift in the foreign policy approach was the role of Ahmet Davutoğlu, who was the chief adviser to the Turkish prime minister at the time, and later himself became minister of foreign affairs and then prime minister. Özal came from an engineering and economics background, while Davutoğlu was an academic in the field of political science and international relations who had published several books and articles. According to him, Islamic and Western paradigms are incompatible because they are based on opposite conceptions of the relationship between God and humankind. In his view, Islamic culture and religion are based on an ontological hierarchy, whereas Western culture is based on ontological proximity. This means that the conflicts and contrasts between Islamic and Western political thought originate mainly from philosophical, historical and methodological points of view. ${ }^{26}$ According to Davutoğlu, Turkish foreign policy during the AKP period should follow five main principles. First, if there is not a balance between security and democracy in a country, it may not have a chance to establish an area of influence in its environs. Second, a "zero problem policy toward Turkey's neighbours" should be established. The third principle is to develop relations with neighbouring regions such as the Balkan Peninsula, the Middle East and the Caucasus by operationalising historical and cultural ties. In this respect, Turkey should use its soft power. The fourth principle is adherence to a multi-dimensional foreign policy by being an active member of intergovernmental organisations, and the fifth is the practice of a pro-active diplomacy in different areas. ${ }^{27}$ At this point, one may argue that Davutoğlu's foreign policy approach adopted a new orientation in the light of the new regional and global developments. Moreover, he defines Turkey as a central country with multiple regional identities that cannot be reduced to one unified category: Turkey's sphere of economic, historical, cultural and religious influence extends to the Middle East, the Balkans, the Caucasus, Central Asia, the Caspian, the Mediterranean, and the Gulf and Black Sea states, all at the same time.

\footnotetext{
${ }^{25}$ Kirişçi, Kemal. "Post Second World War immigration from Balkan countries to Turkey", New Perspectives on Turkey, 12 (1995), 61-77.

${ }^{26}$ Gözaydın, İştar, "Ahmet Davutoğlu: Role as an Islamic scholar shaping Turkey’s foreign policy”, in Islam and International Relations: Diverse Perspectives, Nassef Manabilang Adiong (ed.) (New York: Cambridge Scholars, 2013), pp. 50-9.

${ }^{27}$ Davutoğlu, Ahmet, “Turkey's foreign policy vision: An assessment of 2007”, Insight Turkey, 10.1 (2008), 7796.
} 
On the one hand, Davutoğlu's foreign policy approach seems to have a coherent and systematic theoretical basis. On the other, it can be conceived as problematic for the countries of the region. This new methodology of Turkey trying to be an active actor may easily create anxiety about Turkey's creeping hegemony and sphere of influence. The crux of this matter is that the host state may find that an outsider actor creates problems between itself and its citizens. For example, Turkey has been supporting many projects such as the renovation of Ottoman buildings, the cataloguing of Turkish manuscripts in libraries and conducting public courses on Islamic teachings, presenting itself as the protector of Muslim communities in the Balkans. ${ }^{28}$ In a speech he delivered in Sarajevo in October 2009, Davutoğlu declared that, under the Ottoman rule, the people of the Balkans had lived peacefully for centuries and the time had come to restore the political values, economic interdependence, cooperation and cultural harmony that existed in the Ottoman Balkans. ${ }^{29}$ As shown in Table 1 below, Turkish foreign policy has changed significantly over time and this reflected in the Balkans.

Table 1

\begin{tabular}{|l|l|l|l|}
\hline Periods & $\begin{array}{l}\text { Involvement in the } \\
\text { Balkans }\end{array}$ & Involvement via & Initiatives based on \\
\hline $\begin{array}{l}\text { Early Republican } \\
\text { Era (1923-1946) }\end{array}$ & Dormant & Diplomatic relations & $\begin{array}{l}\text { Diplomats / Formal } \\
\text { authorised individuals } \\
\text { appointed by the state }\end{array}$ \\
\hline $\begin{array}{l}\text { Özal Period (1983- } \\
\text { 1993) }\end{array}$ & Active & Economic relations & $\begin{array}{l}\text { Civil society / } \\
\text { Individual initiatives }\end{array}$ \\
\hline $\begin{array}{l}\text { 2002) } \\
\text { KKP Period (Since }\end{array}$ & More active & $\begin{array}{l}\text { Economic, cultural, } \\
\text { religious and political } \\
\text { relations }\end{array}$ & $\begin{array}{l}\text { Civil society } \\
\text { Individual initiatives/ } \\
\text { Predominantly state } \\
\text { initiatives / Religious } \\
\text { communities }\end{array}$ \\
\hline
\end{tabular}

During the AKP period, as many scholars have noted, the Diyanet, crucially, become one of

\footnotetext{
${ }^{28}$ Öktem, Kerem, New Islamic Actors after the Wahhabi Intermezzo: Turkey's Return to the Muslim Balkans (Oxford: European Studies Centre, 2010).

${ }^{29}$ Ekinci, Mehmet Ugur, "A golden age of relations: Turkey and the western Balkans during the AK Party period”, Insight Turkey, 16.1 (2014), 103-18.
} 
the most influential actors in the Balkans Peninsula. ${ }^{30}$

\section{Turkey's Diyanet: a multi-functional state apparatus}

As with other structures in the society, is not possible to analyse relations between religion and the state in Turkey's Republican era without making comparisons with the Ottoman period and determining the points of rupture and continuity between the two. Scrutinising the institutional dimensions of relations between the state and religion, one may observe that there are both continuity and ruptures in various institutional bodies from the office of the Sheikh ul-Islam to the Şer'iye ve Evkaf Vekâleti (Ministry of Religious Affairs and Pious Foundations) and ultimately to the Diyanet. While in Ottoman times the Sheikh ul-Islam had responsibility for judicial, legal, scholarly, administrative and political duties as well as religious ones, the Şer'iye ve Evkaf Vekâleti, founded by the Ankara government on 4 May 1920, was an institution responsible only for religious matters and pious foundations, but this very effective institution was set at the level of a ministry as far as its place in the administrative hierarchy was concerned. The founding political authority of the Republican era preferred to configure the institution of Presidency of Religious Affairs as an administrative unit under the Prime Ministry. ${ }^{31}$

It seems that the Turkish Republic's founding elite designed the new Turkish state as a modernity project and spared no effort to achieve this goal. In fact, the radical programme of reform and Westernisation that the Republican cadres pursued in the 1920s and 1930s had started earlier, within the Ottoman Empire in the mid-nineteenth century, especially with the reception of Western codes of law and political principles. The main objective of the Ottoman modernisation process appears to have been to sustain the "state", so there was a focus on improving the superstructure. However, the purpose of the new leadership in this period was not only to secularise and modernise the state and the "political", but also to transform society into a modern body. ${ }^{32}$ Thus, in our view, the biggest difference between Republican and Ottoman Westernizations was the spectrum of their telos; and laicism, i.e. the repressive secularisation of society imposed by the state, ${ }^{33}$ was one of the pillars for the Republican

\footnotetext{
${ }^{30}$ See, for example, Öktem, Kerem, “Global Diyanet and multiple networks: Turkey's new presence in the Balkans", Journal of Muslims in Europe, 1.1 (2012), 27-58.

${ }^{31}$ Gözaydın, İştar, "Diyanet and politics”, The Muslim World, 98.2-3 (2008), 216-27.

${ }^{32}$ Gözaydın, İştar, "Religion, politics, and the politics of religion in Turkey", in Religion, Politics, and Turkey's EU Accession, D. Jung and Catharina Raudvere (eds) (New York: Palgrave Macmillan, (2008), pp. 159-76.

${ }^{33}$ Akgönül, Samim, Religions de Turquie, religions des Turcs: Nouveaux acteurs dans l'Europe élargie (Paris: Editions L'Harmattan, 2005), pp. 12 et passim.
} 
founding elite. A first step in understanding religion, politics and the politics of religion in Turkey, a governmental organisation, the Diyanet, must be scrutinised. The Diyanet is an administrative unit of secular Turkish state, but whose components are not secular. It was established in 1924 to maintain services related to Islamic faith and practice, to enlighten society about religion and to administer places of prayer, but also to contribute to the nationbuilding process and to establish popular Islamic communities, mainly brotherhoods.

The Diyanet was established by Act 429 dated 3 March 1340 (1924) "on the Abolition of the Ministries of Şeriyye (Religious Affairs) and Evkaf (Pious Foundations)". With the closing of these two ministries, a new administrative unit, the Diyanet, was brought into being. In other words, the new regulation assigned the management of religious affairs to an administrative bureau, not to a ministry in the cabinet. In terms of administrative law, a ministry is highest in the hierarchy of the central administration, and it is a political unit. Not to locate the institution of "religion" in a political body was a key part of the overall policy of the founding, political decision-making elite of Turkey, who wished to establish a secular state and to create a modern society. They did not want to have within the cabinet a unit dealing with religious affairs. Instead, by assigning religious affairs to an administrative unit, the ruling elite both took religion under their control and at the same time tried to break the potentially sacred significance of the Diyanet.

Even though it is commonly understood that there is not an establish clergy in Islam, in practice, paradoxically, there have always been in all Islamic societies many levels of authority transmitting and interpreting religious massages. That is why it is not only not a surprise that the Diyanet established a pseudo-clergy, but also a paradox to find the former head of the Diyanet (Ali Bardakoğlu), who specifically led the Islamic 'clergy', writing that there is no clergy in Islam. ${ }^{34}$

An assessment of the responsibilities of the Diyanet in this context reveals that duties such as "the management of places of prayer" and "providing correct publications of the Koran" are indeed public services that may be justified as fulfilling a collective need. However, the state also makes use of the Diyanet as an administrative tool to indoctrinate and propagate the official ideology regarding Islam in the course of its responsibility to "enlighten" society about religion and religious education. An interesting point here is the differences between the policies of various administrations over time. Certainly, institutions are organs constituted by

\footnotetext{
${ }^{34}$ Bardakoğlu, Ali, Religion and Society: New Perspectives from Turkey (Ankara: Publications of Presidency of Religious Affairs, 2006), p. 11.
} 
human agents that have their own dynamics according to their agendas, so it is interesting, sociologically and anthropologically, to examine texts produced by various Diyanet authorities.

It has been agreed by various Diyanet authorities over the years that the production and transmission of religious knowledge is quasi-exclusively the task of the institution. "Religious" in this context refers predominantly to Islam. Ali Bardakoğlu, a former president of the Diyanet, has emphasised this mission on many occasions. He states that "the Diyanet has a particular role in the production and transmission of religious knowledge" and suggests that it "provide(s) authentic religious information" 35 - which is actually a normative and centralised Turkish understanding of Sunni Islam.

A preference for using adjectives such as "authentic", "true", "healthy", "objective and truly accurate" indicates an essentialist approach that leads to categorising religions as legitimate and illegitimate. This may be read as a predictable outcome of the legal and political construction of religion in Turkey's Republican period. As for Islam, it has been the task of the Diyanet to define, represent, organise and regulate its public forms, ${ }^{36}$ especially its visibility and/or invisibility. Religious activities outside the oversight of the state are still perceived as a threat and it is interesting to observe the state's responses to them. In fact, the the use of the Diyanet for political and social purposes has led to fewer differences than might have been expected between Kemalist rhetoric and the last decade, with its series of pro-Islamic AKP governments, as far as religious activities outside the oversight of the state are concerned. ${ }^{37}$

Currently, the Diyanet is a significant international actor in the Turkish Islamic sphere because it has the Turkish state's financial and organisational support. Until the military coup of 1980, the Diyanet's access was limited to Muslims inside Turkey, but after the coup the Diyanet expanded its activities into countries with Turkish immigrant populations. Since the early 1980s, the Diyanet has sent imams to Europe to counterbalance the influence of other Islamic communities on Turkish Muslims and to maintain their loyalty to the Turkish state. ${ }^{38}$ To counter undesirable Islamic influences, mainly against the Milli Görüş Movement, the Diyanet sets out to propagate "correct" Sunni Islam through mosques and compulsory classes on Islam, with a strong emphasis on Turkish citizens' duties towards the state and the nation. However, the Diyanet's involvement in international affairs is not limited to migrants with a

\footnotetext{
${ }^{35}$ Ibid., p. 12.

36 Gözaydın, "Diyanet and politics".

37 Öztürk, Ahmet Erdi, “Turkey’s Diyanet under AKP rule: From protector to imposer of state ideology?", Southeast European and Black Sea Studies, 16.4 (2016), 619-35.

${ }^{38}$ Brusse, Wendy A., and Jan Schoonenboom, "The European Union, religion and Turkish Islam", in Turkey and the EU Enlargement, Richard T. Griffiths and Durmuş Özdemir (eds) (Istanbul: Istanbul Bilgi University Press, 2004), 69-88.
} 
Turkish background; it also claims a role as an actor in regions such as the Balkans and the Caucasus.

\section{Diyanet activities in the Balkan Peninsula under AKP rule}

For more than a decade, Turkey has been enhancing its relations with the Balkan countries, which, under the impact of Davutoğlu's foreign policy strategy, demonstrate not only Turkey's approach to matters of strategic, economic and socio-cultural importance, but also the reflection of its on-going political, economic and social transformation on foreign policy. ${ }^{39}$ Moreover, Davutoğlu has complained that Turkey's previous governments' secularist sensitivities and fears have prevented Turkey from engaging in a stronger relationship with Muslims in the Balkans and hence from utilising a significant socio-cultural resource. These comments and policies may be read to mean that, in Turkey's foreign affairs, religion and religious actors have come to a prominent position since Davutoğlu became a decision-maker.

The role of the Diyanet may be defined as being to supply various types of necessities, such as financial support for mosque construction and restoration, providing copies of the Qur'an and other books to be used for religious education and educating the religious officials of mainly Muslim communities in the Balkans. ${ }^{40}$ For instance, according to Y1ldıray Kaplan, Head of the Diyanet's Department of Publications in Foreign Languages and Dialects, one of the more prominent functions of the Diyanet is to provide true and healthy Islamic sources to their Muslim brothers, including publishing not only the Qur'an, but also other relevant resources. Kaplan notes that the Balkan Muslims' confrontation with almost losing their religious awareness during the Yugoslavia period is one of the fundamental reasons why Turkey, as a Muslim brother, has a duty to restore their religious knowledge. ${ }^{41}$

On the other hand, some Turkish officials in the Balkan region reveal quite different perspectives and outcomes regarding to the Diyanet's activities in the region. According to them, Turkey has been trying to teach religion to Balkan Muslims and this conduct has been receiving various reactions from the regional communities. First, the authorities in the Balkan countries see the activities of the Diyanet as a Turkish intervention that exploits religion and so they see the Diyanet as a Trojan horse. Second, according to a Turkish Foreign Ministry representative in the Balkan region, some of Balkan Muslim community leaders have been

\footnotetext{
${ }^{39}$ Aras, Bülent, "Davutoğlu era in Turkish foreign policy revisited", Journal of Balkan and Near Eastern Studies, 16.4 (2014), 404-18.

${ }^{40}$ Öktem, Kerem, "Between emigration, de-Islamization and the nation-state: Muslim communities in the Balkans today", Southeast European and Black Sea Studies, 11.2 (2011), 155-71.

${ }^{41}$ Information based on an interview with Yildiray Kaplan by the authors on 26 January 2016.
} 
becoming resentful of the Diyanet's hypocritical activities among them. ${ }^{42}$ Thus, Hasan Makiç, Bilhaç, former Mufti, declared that, although it is perfectly acceptable for the Turkish Diyanet to provide support for their religious brothers in some matters ${ }^{43}$ they should also be aware that Balkan Muslims are totally independent and it is only Islam that should be obeyed, not any other agency. ${ }^{44}$

In order for any Diyanet services to be provided abroad, legal procedures initially require the official and registered Muslim bodies, communities and groups or/and Turkish citizens within them to send an official registration statement, which should clearly explain their request. Only then can the Diyanet act via its representatives and other institutions such as the Diyanet Foundation (TDV). Nevertheless, if the Diyanet determines that there are certain needs, it may offer some services, but this procedure is very exceptional. In any case, it seems that, as soon as the Diyanet enters a country in one way or another, the Diyanet officials start to establish relations with Muslim communities and other groups by using Turkey's main foreign policy strategies. That is, they use language that refers to the Ottoman past and of the shared Islamic heritage. The instrumentalisation by the agents of the Diyanet of a reconstructed Ottoman past and the Islamic identity that is held in common is clear to see.

According to some Diyanet officials, most Muslim communities in the Balkan countries call on Turkey to meet their needs, since they perceive Turkey to be a rich, strong country that can easily help them. If Turkey fails to respond to their requests, the Balkan countries' Muslim communities apply to other Muslim countries. For instance, in 2012, Slovenian Muslim communities, which are mostly made up of Bosnian, asked for financial aid to build a mosque in Ljubljana, the capital of Slovenia, but the Diyanet could not supply all the funding, so the Slovenian Muslim communities got financial aid from Kuwait. ${ }^{45}$

In 2014, the TDV announced plans to build the largest mosque in the Balkans in the Albanian capital Tirana, despite the low attendance at the city's sole existing mosque. It would have been expected that the activities of the Diyanet in a given country should be related to the proportion of Muslim and Turkish oriented citizens there, but Turkey is following an entrist intervention policy by first becoming involved in order then to change the society. Naturally, when the Turkish and/or Muslim population is greater, negative reactions are milder, but when

\footnotetext{
${ }^{42}$ Information based on interviews with two anonymous Turkish Foreign Ministry officials by the authors on 5 May 2016.

${ }^{43}$ For instance, the TDV paid the wages of the imams in the flood-stricken Bosnia and Herzegovina between 2007 and 2009, in addition to restoring mosques and other religious buildings that were damaged in the flood.

${ }^{44}$ Information based on an interviews with Hasan Makiç, Bilhaç Müfti in Sarajevo by the authors on 7 May 2015.

${ }^{45}$ Information based on interviews with Kazım Türkmen (head of Diaspora Turks), and Kemal Hakkı Kılıç (head of Eurasian Countries) of the Diyanet's Foreign Affairs Department, by the authors on 26 January 2016.
} 
the overwhelming majority belong to religions other than Islam the Diyanet activities are much more unwelcome.

Since the late 1980s, the Diyanet has had a new role in Turkey's foreign policy by engaging into contacts with other Muslim communities. In this respect, the Balkan Peninsula has a significant position with a Muslim population of approximately 10 million as a potential target. This means that the approach of the Turkish state under AKP rule and the instrumentalisation of the Diyanet are quite similar to the logic of investment. However, even though the AKP elites think that their strategy will not be recognised by local Muslims, the latter are pretty much aware of the policy mind-set of Turkey's AKP.

The Diyanet has been playing a prominent role not only in providing basic religious services to Muslims, but also in organising and taking charge of various other types of activity. For instance, since 1995 the Diyanet has been organising the meetings of the Eurasian Islam Council (Avrasya İslam Şurast) in order to bring various Muslim bodies together and establish communication between them. At these meetings, discussions on Islamic practice, educational activities and regional religious problems take place at the Diyanet's invitation. In 2000, the meeting was held in Sarajevo and in 2002 in Kosovo. Since 2007, the Diyanet has also been organising an annual meeting specifically for the representatives and leaders of the Balkan Peninsula's Muslim communities. Cooperation between the groups and countries, new perspectives and 'Islamophobia' in the Balkans have been among the most discussed issues at these meetings. ${ }^{46}$ These summits are not only one of the clear signs of the importance of the Balkans for the Diyanet, but also reveal the way Turkey perceives itself to be the big brother. This crystal clear message shows that Turkey has positioned itself as the leader of the Muslim groups in the Balkan Peninsula.

The Diyanet has also been providing scholarships for religious education for many students from the Balkan countries through the TDV. According to Diyanet country statistics for 2012, full scholarships were provided for more than 1000 students with religious interests to study in Turkey at various educational levels. The ratio of scholarships to the number of Muslims in a given country is significantly higher in countries with significant Turkish communities. The TDV also has been opening colleges and institutes to train preachers in Bulgaria and Romania. Addition to these activities, there are many twinning projects in the Balkans aimed at developing new areas of cooperation between Turkey and the Balkan countries via the Diyanet.

\footnotetext{
${ }^{46}$ Öktem, "Global Diyanet".
} 
From a country-based analysis, Turkey's current international relations in the Balkans may be summarised as in the following chart:

Table 2

\begin{abstract}
Albania: Albania's population is over 70\% Muslim. Despite the fact that it has a secular structure equally distinct from all religions, there has been competition both between various Muslim groups and between religious and secular Muslims. Turkey has been trying to involve itself in this multi-sided competition through its state and civil society oriented apparatuses. Many schools and educational institutions at different levels have been established and Turkey has also been building Albania's biggest mosque, set to cost more than $€ 30$ million, in the capital Tirana.
\end{abstract}

Bosnia-Herzegovina: Bosnia-Herzegovina has a Muslim population of over 2 million and is a Muslim-majority country. The state is secular and formally equally separated from all religions. Nevertheless, the Diyanet, the TVD, and Turkish-based transnational organisations and communities have been in active in various areas for more than 15 years.

Bulgaria: Bulgaria has a significant Muslim minority, amounting to more than $15 \%$ of its population. Almost $80 \%$ of them are Turkish speakers (the rest are Bulgarian-speaking Muslims and Roma). Bulgaria is constitutionally a secular country, but Orthodoxy Christianity has a preferential status as the traditional religion of the state and Orthodox Christian interests interfere with and obstruct community life. For example, after 9/11 the anti-Muslim, antiTurkish party (ATAKA) generally supported heavy discrimination against Muslims. The Diyanet, the TVD and Turkish-based transnational organisations and communities have been in active in various areas for more than two decades.

Greece: Almost 1.5\% of the population are Muslims, most of them Turkish speakers. On the one hand, Orthodoxy Christianity is considered part of Greek national identity and is highly suspicious of Muslim minority, although there are signs that this is changing. On the other, there is a nationalist party with an anti-Muslim discourse (LAOS). There has also been an intense conflict between elected and appointed muftis since 1989. The Diyanet and the TVD have been active for more than two decades.

Kosovo: When Kosovo declared its independence from Serbia on 17 February 2008, Turkey became one of the first countries to give official diplomatic recognition to Kosovo as a sovereign nation. The number of ethnic Albanian Kosovars living in Turkey is estimated to be higher than that of those living in Kosovo itself. There are 20,000 Turkish speakers in Kosovo, and Turkish is one of the country's official regional languages. Almost $90 \%$ of the population are Muslims. Although the state has a secular structure, equally separate from all religions, there has been competition both between various Muslim groups and between religious and secular Muslims. Turkey has been trying to involve itself in this multi-sided competition through its state and civil society oriented apparatuses. Many schools and institutions were established before the declaration of independence.

Macedonia: Macedonia has a very large Muslim minority amounting to almost $35 \%$ of the population. More than $10 \%$ of them are Turkish speakers. Although Macedonia is a secular country, Orthodox Christianity has an elevated status. Muslims are free to organise their community life. The Diyanet, the TVD and Turkish-based transnational organisations and communities have been active in various areas for more than a decade. 
Slovenia: In 2014, there were around 48,266 Muslims in Slovenia, about 2.4\% of the total population, and they are ethnically mostly Bosnians and other Slavs. Although the Turkish population is insignificant, both the Diyanet and the TVD have been trying to be active in the country since the early 2000 s.

Serbia: Serbia has a significant Muslim minority making up almost 7\% of the population and mostly Bosnian originated. Serbia gives preference to Orthodox Christianity and the state interferes in community life. Neither the Diyanet nor other Turkish-based institutions and organisations have significant activities in Serbia because of the negative attitude of the state and most of the population.

Romania: Romania has a secular constitution and state structure. The very small minority of Muslims - less than $1 \%$ of the population - are ethnically mostly Turks and Bosnians. The Diyanet has almost no activities.

Croatia: Muslims in Croatia make up less than $2 \%$ of the population. The Diyanet and the TVD have no visibility.

Montenegro: Turkey officially recognised Montenegro on 12 June 2006 and diplomatic relations were established on 3 July 2006. Intensive and successful high-level visits and contacts between the two countries are on-going. Montenegro is a secular country. It has a very large Muslim minority, constituting over $30 \%$ of the population, but there is no Diyanet activity.

\section{Conclusion}

Turkey's ambition, as reflected in its foreign policies, to act as a regional leader in the Balkan Peninsula varies in terms of impact; it is welcomed by some, but eyed suspiciously by others. The Diyanet is trying to shape Balkan Islam in the image of its own understanding of Islamic doctrine and practice, while using its external relations to legitimate itself as the heir of the Ottoman Islamic system, the Meşihat. A significant in Turkey's foreign policy, whose roots may be traced back to the 1990s, has emerged under the AKP, particularly due to the influence of Ahmet Davutoğlu, starting from his becoming the chief advisor to Prime Minister Erdoğan (2003-2009). Becoming Minister of Foreign Affairs in 2009, Professor Davutoğlu's influence reached its peak when he applied his academic thesis to foreign affairs when he became prime minister (2014-2016). A foreign policy based on the assumption of an Ottoman heritage, common cultural values and a shared religion in the Balkans has been maintained, even after Davutoğlu's resignation.

The Diyanet is an ideological state apparatus that has become an ontological necessity in Turkey to regulate and manage the religious filed on behalf of the state. As the leading politicians in the AKP are becoming increasingly authoritarian and dominant, the Diyanet has been a device used to both legitimise and impose new political preferences, both domestically and abroad, through the instrumentalisation of its religion-based authority. ${ }^{47}$ Furthermore, it is 47 Öztürk, Ahmet Erdi., and Semiha Sözeri, "Diyanet as a Turkish Foreign Policy Tool: Evidence from the
Netherlands and Bulgaria, Politics and Religion, 2018, 1-25. https://doi.org/10.1017/S175504831700075X. 
very much to be expected that the Diyanet will manoeuvre to even partially grasp such a role in the Balkans, with its prominent Muslim population and its imagined idealised Ottoman past.

However, the application of politics and policies in the Balkans by Turkey and its Diyanet have not exactly met their expectations. Most importantly, Turkey's hegemonic and patronising attempts via the Diyanet to intrude upon the domestic politics of the countries in the Peninsula have not met with a positive response in the Balkans, particularly from the dominant socio-political structures. Another issue is lies Turkey's perception of the region as a singular entity, while it is fact made up of separate countries with different histories, different demographic structures and different dynamics. Furthermore, even Balkan communities that are relatively more accepting withdraw unequivocal support as soon as they sense that they are being trespassed upon. Thus it is not hard to conclude that the success story narrated by Ankara is not told in the same way in the Balkans; at the end of the day, it always takes two to tango. 